\title{
Note
}

\section{Unclear Standards Create an Unclear Future: Developing a Better Definition of Unitary Status}

\author{
Monika L. Moore
}

\section{INTRODUCTION}

When the federal courts began supervising the desegregation of public schools in the latter half of the twentieth century, no one intended this regulation to continue for an indefinite period of time. The expectation was that the courts would return schools to local control after the districts had complied with their federal desegregation orders. In the year 2001, however, over 400 school districts were still under federal court supervision, ${ }^{1}$ making the federal bench the largest school district in the country. Since many of these school districts have operated under court supervision for more than three decades, the reason that they are still under court supervision is not that they have failed to desegregate. Instead, at least two plausible explanations demonstrate why so many districts remain under desegregation orders. One explanation results from the unclear standard the Supreme Court has developed to define when courts should release school districts from supervision. The other explanation arises from the process school systems must undergo to regain local control.

First, the Supreme Court has not provided the lower courts with any concrete standards to help them decide when they should release school districts from supervision. The Court has only vaguely explained that lower courts should remove school districts from court orders when the districts

1. Edward Blum \& Roger Clegg, Pyrrhic Victory, FULton COUNTY DAILY REP., Nov. 29, 2001 , at 6 
have attained "unitary status." It has then listed six educational areas, commonly known as the Green factors, ${ }^{3}$ from which school districts must eliminate all vestiges of the prior dual system before the districts can return to local control. The Court has not offered any more guidance on this question. Therefore, lower courts have developed their own measures, and this fact explains why some school districts are still under court control, even though they have achieved a higher level of desegregation than other districts that courts have already released from supervision.

Second, the process that the courts have developed to determine when to release districts from their desegregation orders has made it possible for school systems to remain under supervision indefinitely. Typically when a school district first came under supervision, the court required the district to develop an acceptable desegregation plan. In many cases, if the district did not design a satisfactory plan, the court developed its own plan. The court then removed the case from its active docket and did not continue to monitor the district's progress unless an outside party brought a problem to the court's attention. Consequently, if no party brought any complaints to the court, a school district could remain under supervision years after it had achieved its desegregation goals.

Theoretically, under this process, a school system should not remain under supervision after it has fulfilled its desegregation obligations because even if no other party reactivates the litigation, the school system itself has the power to request that the court release it from control. However, school systems have several motives to want to remain under court orders indefinitely, and so the potential exists for a system to remain under supervision many years after it has fully desegregated its schools. Aside from the fact that this prolonged supervision violates the principle that schools should be under local control, it also often works to the detriment of students in the system.

Consequently, this Note argues that the Supreme Court should have more clearly defined the term "unitary status." Since the Court offered little clarification on this point, several commentators have attempted to suggest more quantifiable methods to assess when a system has achieved unitary status. This Note analyzes these proposals and explains why these suggestions are all problematic.

This Note then offers a new proposal for how the Court could have defined unitary status. Unlike the proposals of some scholars that attempt to offer substantive definitions of some of the Green factors, this proposal focuses on providing procedural clarification. This proposal, called the "twelve-year plan," asserts that a court should end supervision of a system

2. Green v. County Sch. Bd., 391 U.S. 430, 438 (1968).

3. Id. 
under a desegregation order twelve years after it has removed the case from its active docket if the district has complied with the order while under supervision. During this twelve-year period, the court would more closely monitor the school system's compliance by requiring annual reports from the system detailing its progress in remedying the vestiges of the prior dual system.

The selection of the twelve-year period of court supervision is not arbitrary. Instead, it stems from the fact that a school system has substantially harmed all students who attended segregated schools under the prior dual regime. Consequently, the twelve-year plan requires a school to remain under court supervision until all of the students who had standing in the desegregation suit have a chance to graduate.

The twelve-year plan is a superior alternative to the status quo because it addresses the four main problems that stem from the current system. First, inflexible desegregation orders restrict the ability of districts to adopt creative policies to address their most current and pressing needs. Second, school districts must spend thousands of dollars in litigation fees to have the courts release them from supervision. Third, parents have no clear expectation as to when the courts will remove desegregation orders and their children will have to switch schools. Finally, the longer that districts are under desegregation orders, the more difficult it becomes to ensure that the districts are only addressing de jure segregation and have not adopted policies that focus on de facto segregation.

In response to this first concern, the twelve-year plan recognizes that school districts need the freedom to implement policies to address changing needs instead of being hindered by requirements that they meet rigid racial ratios long after the district has addressed, to the extent possible, the evils caused by de jure segregation. The twelve-year plan combats the second problem concerning the high costs of litigation in several ways. It ensures that courts are more involved in monitoring a school system's progress and in preventing noncompliance, and it also provides a concrete time frame for when supervision should end. These attributes of the plan would prevent the need for the costly litigation that plagues the current system. Similarly, the twelve-year plan solves the problem of parental expectations, because it gives individuals a concrete idea of when their schools' assignment plans will change. Finally, the limited timespan recommended by the twelve-year plan would minimize the extent to which school districts under desegregation orders feel that they are required to address imbalances that result from de facto segregation.

The problems that result from the Court's vague unitary status standards and the benefits the twelve-year plan would create become evident through a case study of the Charlotte-Mecklenburg School System (CMS). In 1971, CMS became the first school system to use busing to 
desegregate its schools when the Supreme Court approved the use of this desegregation method in Swann v. Charlotte-Mecklenburg Board of Education. ${ }^{4}$ The courts then failed to monitor CMS's desegregation progress any further until a group of parents asked a federal judge to end the court order in 1997..$^{5}$ The school system waged an active defense against the plaintiffs' suit, claiming that it had failed to comply with the court order. After years of litigation, a federal court of appeals finally concluded that CMS had obtained unitary status. ${ }^{6}$

An examination of the CMS litigation clearly illustrates the four problems that result when school systems remain under court supervision for too long. Furthermore, a hypothetical analysis of how circumstances would have been different for CMS if the court had facilitated the system's desegregation through the twelve-year plan illustrates the merits of this proposal. Finally, an assessment of the steps CMS has taken since the court removed it from supervision helps dispel some of the main concerns that might surround the use of the twelve-year plan.

Part II of this Note begins by providing a synopsis of the limited guidance that the Supreme Court has given to lower courts concerning how to determine whether a school has achieved unitary status. It then addresses various measures lower courts have developed in light of this ambiguous guidance. Part III analyzes the few suggestions that scholars have offered to quantify the concept of unitary status and articulates the flaws in these proposals. It also introduces the twelve-year plan, this author's suggestion for how unitary status could have been more clearly defined. This Part identifies the plan's strengths and addresses potential criticisms that might arise concerning the feasibility of the proposal. Part IV explains why a clearer definition of unitary status is necessary by detailing the history of CMS's actions to comply with its desegregation order. It applies the twelveyear plan to the facts of the CMS litigation, and it demonstrates how this plan could have prevented the problems that the school system's parents and students faced as a result of the courts having allowed CMS to remain under the court order for too long. Part V uses the CMS desegregation experience both to identify other concerns the twelve-year plan may generate and to demonstrate why these concerns are unfounded. Part VI concludes.

4. 402 U.S. 1, 30-31 (1971).

5. Capacchione v. Charlotte-Mecklenburg Sch., 57 F. Supp. 2d 228, 239-40 (W.D.N.C. 1999), aff'd sub nom. Belk v. Charlotte-Mecklcnburg Bd. of Educ., 269 F.3d 305, 335 (4th Cir. 2001) (en banc), cert. denied, 122 S. Ct. 1537 (2002).

6. Belk, 269 F.3d at 335 . 


\section{The VAGUe DeFINITION OF UNITARY STATUS}

The Supreme Court has clearly stated that "[f]rom the very first, federal supervision of local school systems was intended as a temporary measure to remedy past discrimination." The Court has given little guidance, however, as to when lower courts should release schools from the court orders requiring them to execute desegregation plans. In its 1968 decision in Green v. County School Board, the Supreme Court stated that courts should remove schools from supervision when the schools achieve "unitary status," or when "racial discrimination [has been] eliminated root and branch." The Court further clarified that schools would not achieve unitary status until six aspects of education no longer reflected any of the vestiges of past racial discrimination. These areas, now commonly called the Green factors, are student assignment, faculty, staff, transportation, extracurricular activities, and facilities. ${ }^{9}$ Yet, the Court offered no further guidance to lower courts concerning how to determine when a Green factor no longer reflects the vestiges of past racial discrimination.

Later in Board of Education v. Dowell, the Court explained that unitary status is achieved if "the Board had complied in good faith with the desegregation decree since it was entered" and "the vestiges of past discrimination had been eliminated to the extent practicable."10 However, the concept of "to the extent practicable" is just as unclear as the concept of "unitary status."

It is perhaps understandable why the Supreme Court did not offer the lower courts more direction. After all, every school district is under a different district court order detailing the expectations the school district must meet in order to achieve unitary status. Furthermore, the Supreme Court has openly acknowledged that it has not offered a concrete definition for the concept of unitary status because it did not believe that it needed to explicate further this term. " "[T]hink[ing] it [was] a mistake to treat words such as 'dual' and 'unitary' as if they were actually found in the Constitution," the Court has explained that it was "not sure how useful it [was] to define these terms more precisely." ${ }^{12}$ However, despite the Court's reasoning, the Fourteenth Amendment articulates the constitutional right to equal protection that unitary school systems promote and dual systems violate. Also, ironically, since the Court has basically limited its guidance concerning when lower courts should release schools from supervision to

7. Bd. of Educ. v. Dowell, 498 U.S. 237, 247 (1991).

8. 391 U.S. 430,438 (1968).

9. Id. at 435 .

10. 498 U.S. at 249-50.

11. Id. at 245-46.

12. Id. 
the use of the term "unitary status," the lower courts have overemphasized this term and given it great importance, even though it appears that this outcome was not the Court's intention.

As a result, district and circuit courts have developed different and somewhat arbitrary criteria to measure when school districts have eliminated the vestiges of prior discrimination. In Morgan v. Nucci, the First Circuit looked to the racial imbalance in schools during the period that a district was under a desegregation order to determine whether the school district had achieved unitary status in school assignments. ${ }^{13}$ In Hoots $v$. Pennsylvania, a district court not only considered whether specific schools had achieved acceptable racial ratios, but also whether individual classrooms had a satisfactory racial balance, before ruling that the school district had achieved unitary status. ${ }^{14}$

Courts have also developed a variety of different measurements concerning the other five Green factors. When evaluating whether school districts had achieved unitary status concerning faculty and staff assignments, one court considered whether the district's current employment practices were nondiscriminatory and whether the district had remedied the effects of prior discrimination..$^{15}$ Another court found that the increase in the number of African-American principals in the district was an important consideration when determining that the school district had achieved unitary status. ${ }^{16}$

Outside of the measures that specifically relate to the Green factors, courts have recognized a myriad of other ancillary factors as important considerations when determining whether school districts have achieved unitary status. For instance, some courts have found that the presence of minority members in school administration is a helpful indicator of a district's progress. ${ }^{17}$ In addition, at least one court has considered the support for desegregation demonstrated by local African-American and white communities as an indicative measure. ${ }^{18}$ This court took particular note of the fact that the community as a whole had "accepted public school desegregation in a spirit of cooperation and good will,"19 and recognized that the community had demonstrated a willingness to sustain the newly desegregated school by supporting a school bond. ${ }^{20}$

13. 831 F.2d 313, 320-21 (1st Cir, 1987).

14. 118 F. Supp. $2 d 577,585$ (W.D. Pa. 2000).

15. Fort Bend Indep. Sch. Dist. v. Stafford, 651 F.2d 1133, 1140 (5th Cir. 1981).

16. Whittenberg v. Sch. Dist., 607 F. Supp. 289, 299 (D.S.C. 1985).

17. Riddick v. Sch. Bd., 784 F.2d 521, 528 (4th Cir. 1986); see also Morgan, 831 F.2d at 321.

18. United States v. Corinth Mun. Separate Sch. Dist., 414 F. Supp. 1336, 1339-40 (N.D. Miss. 1976).

19. Id. at 1339 .

20. Id. at 1340 . 
Equally absent from the Supreme Court's opinions concerning desegregation orders is any clarification concerning how many years a school district must comply with a desegregation order before a court will release the school from its supervision. In Board of Education v. Dowell, the Court explained that courts should release school districts from desegregation orders after the districts have complied with the orders for "a reasonable period of time." ${ }^{21}$

However, the Court has failed to offer more concrete guidance on this point. Consequently, the district and circuit courts have developed a number of different standards for how many years that a school district must comply with the desegregation order for the court to find that it has achieved unitary status. For example, at least one appellate court has asserted a vague opinion on this question, stating that courts can release school districts from supervision after the districts have complied with the desegregation orders for a period of "several years." 22

Other courts have offered more specific opinions. One Mississippi district court released a school district from its desegregation order after the district had complied with the order for seven years. ${ }^{23}$ Another district court in Oklahoma removed a school district from supervision after it had met the requirements of the desegregation plan for only five years. ${ }^{24}$ Accordingly, across the country, the standard for the duration of a desegregation order has varied by school district.

This analysis of how courts have attempted to measure a school district's progress toward achieving unitary status demonstrates one of the main problems inherent in the current jurisprudence concerning unitary status. Under the present regime, courts have developed their methodologies for evaluating compliance with a desegregation order ex post instead of when the desegregation order was first implemented. Consequently, school districts have had little notice about how courts will evaluate their progress, and furthermore they lack a clear idea of when they might be eligible for release from court supervision. This lack of information is problematic in a system that places the burden on the school district or some other outside party to request that the court remove the desegregation order. It is consequently not surprising that many school systems remain under court orders long after they have complied with them.

21. 498 U.S. 237,248 (1991).

22. NAACP v. Georgia, 775 F.2d 1403, 1413 n.12 (11 th Cir. 1985).

23. Corinth, 414 F. Supp. at 1337.

24. See Dowell, 498 U.S. at 241 (discussing a 1977 court order finding compliance with and dissolving the 1972 school desegregation program). 


\section{A PROPOSED CLEARER DEFINITION OF UNITARY STATUS}

An examination of the vague jurisprudence concerning unitary status has identified the problems inherent in the current system. School systems have no clear idea of when courts will release them from court supervision. Consequently, they often remain under court supervision for too long. These characteristics of the current system are problematic for a number of reasons. First, schools that are under desegregation orders for several decades lack the ability and incentive to adopt creative new policies to address the system's most pressing needs. ${ }^{25}$ A school system's needs change over time, and in the twenty-first century many black parents no longer believe that an integrated education will ensure that their children receive the best quality education. ${ }^{26}$ As Professor Drew Days has noted, many blacks have begun to rethink the integrative ideal because of "[c]oncerns about the burdens blacks have had to carry in the desegregation process, the degree to which integration requires assimilation and rejection of black values and institutions, and the seemingly intractable problems presented for largely black school systems in educational extremis."27 However, if the school is still under a desegregation order, the district's top priority when designing school policies is to ensure that it is in compliance with the order.

Secondly, schools that are under desegregation orders typically have to spend thousands of dollars in litigation fees when they seek termination of court supervision. ${ }^{28}$ In addition, when a school is under a desegregation order, parents typically have no idea when the court will remove the order,

25. See, e.g., Joel B. Teitelbaum, Comment, Issues in School Desegregation: The Dissolution of a Well-Intentioned Mandate, 79 MARQ. L. REV. 347, 367 (1995) (explaining that " $[\mathrm{t}] \mathrm{he}$ special legal obligations under which these districts operate could potentially interfere with the competing goal[] of school reform" and that the possibility for conflict between these two goals exists for political and structural reasons, as well as the fact that schools under desegregation orders operate under special limitations).

26. Davison M. Douglas, Swann Song for the Busing Era, 3 GREEN BAG 2D 1, 2 (1999); see also Drew S. Days III, Brown Blues: Rethinking the Integrative Ideal, 34 WM. \& MARY L. REV. 53,55 (1992) (noting that "given the initial hope that desegregation would increase the quality of educational opportunity for black students," it is disappointing that "the desegregation process has not necessarily brought about improvements"). While this Note acknowledges that integration is no longer the greatest concern of many parents with regard to educational reform, this Note strongly affirms that integration is an important and necessary goal for school systems after courts have removed their desegregation orders. Consequently, Part V discusses a number of ways school systems can still achieve integration when they are no longer under court supervision.

27. Days, supra note 26 , at 74 .

28. Gary Orfield \& David Thronson, Dismantling Desegregation: Uncertain Gains, Unexpected Costs, 42 EMORY L.J. 759, 769 (1993) (noting that the DeKalb County School System had already spent more than one million dollars in litigation fees before participating in arguments on remand from the Supreme Court to achieve a declaration of unitary status and acknowledging the high costs of dismantling desegregation decrees in general). 
at which time their children may have to transfer schools. ${ }^{29}$ It is important for parents to have a reasonable expectation of when their child's student assignment may change because school changes have psychological impacts on children and often create logistical problems for parents. Finally, when schools remain under desegregation orders for prolonged periods of time, they begin to address racial imbalances caused by de facto segregation as well as de jure segregation. ${ }^{30}$ When a school district is under a desegregation order for several decades, racial imbalances in schools can begin to occur because of population shifts and demographic changes. Since the system is under the order, the school district has to make adjustments to its student-assignment plan to remain in compliance with the order. The courts, however, only intended for schools under desegregation orders to address de jure segregation, not imbalances that occur due to de facto segregation. ${ }^{31}$ Recognizing the harmful effects of the vague nature of the unitary status concept raises the important question of how this term could be more clearly defined.

\section{A. Scholars' Suggestions for How To Define Unitary Status}

Various observers have attempted to suggest more tangible and quantifiable ways to measure a school system's progress toward achieving unitary status. Yet, these ideas run into roadblocks. For instance, one measure that has been suggested is that a district is unitary when there is no

29. See infra note $\mathbf{1 2 9}$ and accompanying text (detailing the uncertainty that parents in the Charlotte-Mecklenburg School System faced while awaiting the end of the litigation to determine whether the system was unitary).

30. See infra Sections IV.B, IV.D (discussing the Charlotte-Mecklenburg School System's attempts to address de facto segregation while under its court desegregation order).

31. In Swann, the Court established the distinction between de jure and de facto segregation, making clear that only de jure segregation was unconstitutional. See Teitelbaum, supra note 25, at 354-55 (citing Swann v. Charlotte-Mecklenburg Bd. of Educ., 402 U.S. 1, 17-18 (1971)). Furthermore, the Court made clear that "[n]either school authorities nor district courts are constitutionally required to make year-by-year adjustments of the racial composition of student bodies once the affirmative duty to desegregate has been accomplished and racial discrimination through official action is eliminated from the system." Swann, 402 U.S. at 31-32; see also Keyes v. Sch. Dist. No. 1, 413 U.S. 189, 208 (1973) (reaffirming that a constitutional violation does not exist unless a school district has engaged in de jure segregation, evidenced by the intent to segregate).

There are scholars who have disagreed with the Court's decision to limit unconstitutional segregation to only de jure segregation. See, e.g., Owen Fiss, School Desegregation: The Uncertain Path of the Law, 4 PHIL. \& PUB. AFF. 3, 19, 39 (1974) (advocating that society "abandon the illusory search for the incidents of past discrimination" and recognize a distributive conception of the remedy for segregation because desegregated schools are a normative right); see also Steven I. Locke, Comment, Board of Education v. Dowell: A Look at the New Phase in Desegregation Law, 21 HOFSTRA L. REV. 537, 560 (1992) (arguing that instead of distinguishing between de jure and de facto segregation, courts should consider residential segregation a vestige of past de jure segregation). This Note does not seek to enter this debate between the courts and desegregation scholars. Instcad, it simply attcmpts to create a clearer definition of unitary status within the Court's interpretation of what actions constitute unconstitutional segregation. 
longer a possibility that it can achieve any further racial balancing. ${ }^{32}$ In theory, however, there is always some new policy a school district could implement to desegregate further its schools. Consequently, school systems under this definition of unitary status could remain under desegregation orders forever. At least one court has recognized the problem inherent in this idea and has held that a court cannot keep a school under a desegregation order simply because more desegregation is theoretically possible. $^{33}$

Another suggestion concerning how to define unitary status is that school systems have achieved this goal "when the numbers are right." "34 Professor Melva Ware has defined this concept to mean that a system complies with a court desegregation order when test scores reflect that any continuing discrepancies between the success of African-American and white students are "incidental." Courts could measure whether these quantifiable indicators are "incidental" by comparing a school district's test scores with state and national averages. ${ }^{36}$ This measure is problematic, however, because different areas of the country are wealthier than others, and different states have different methods of financing and running their schools, which might create discrepancies that have nothing to do with remnants of a prior dual system. Furthermore, the Supreme Court made clear in Missouri v. Jenkins II that the appropriate test of whether a district has achieved partial unitary status is not whether student achievement levels reach national norms. ${ }^{37}$

On the other hand, Charles Willie and Michael Fultz have advanced a different test to evaluate unitary status based on a study they conducted that analyzed four school systems they believed had developed successful models. ${ }^{38}$ Their study found that one mistake school systems and courts have commonly made when designing desegregation plans is that they only focus on providing a desegregated educational experience for one race. ${ }^{39}$

32. See Capacchione v. Charlotte-Mecklenburg Sch., 57 F. Supp. 2d 228, 255 (W.D.N.C. 1999), aff'd sub nom. Belk v. Charlotte-Mecklenburg Bd. of Educ., 269 F.3d 305 (4th Cir. 2001) (en banc), cert. denied, 122 S. Ct. 1537 (2002).

33. Calhoun v. Cook, 525 F.2d 1203, 1203 (5th Cir. 1975)

34. See Melva L. Ware, School Desegregation in the New Millennium: The Racial Balance Standard Is an Inadequate Approach to Achieving Equality in Education, 18 ST. LOUIS U. PUB. L. REV. 465, 479 (1999).

35. Id. at 478 .

36. Id

37. Cheryl Feutz, The Supreme Court's Reanalysis of School Desegregation Remedial Decrees: Is the Majority Placing Subtle Limits on the Trial Court's Vast Equitable Discretion?, 61 Mo. L. REV. 679, 682 (1996) (citing Missouri v. Jenkins II, 515 U.S. 70, 101 (1995)).

38. Charles Vert Willie \& Michael Fultz, Comparative Analysis of Model School Desegregation Plans, in SchoOl Desegregation Plans That Work 197, 197-200 (Charles Vert Willie ed., 1984) (analyzing data collected in the Boston, Milwaukee, Seattle, and Atlanta school systems).

39. Id. at $197-98$. 
For instance, many systems have concentrated on ensuring that AfricanAmerican students attend schools where they are not the majorityhowever, these desegregation plans have left many predominantly white schools. ${ }^{40}$ Willie and Fultz argue that to be truly effective, desegregation plans must ensure that the system does not operate any schools where racial minorities comprise less than twenty percent of the student body. ${ }^{41}$ Their survey demonstrated that school systems that have been the most successful in desegregating their schools focus on the twin goals of increasing educational advancement and improving racial diversity for all students. ${ }^{42}$

The strength of Willie and Fultz's plan is that they identify that one necessary component of a successful plan to achieve unitary status is to set forth quantifiable requirements that school systems must meet to ensure that their students are receiving an integrated education. However, their suggestions do not consider the question of how long school districts must remain under court supervision and the harms that result when school districts operate under court orders for too long. Consequently, their plan does not consider many of the problems that result from the system currently in place.

Finally, Thomas Chandler has proposed that courts should engage in two levels of hearings to determine whether schools have achieved unitary status. ${ }^{43}$ Under his plan, the school board would have to request the first hearing after it had operated under its desegregation plan for a period of years. The burden of proof would be on the school board to prove that it had eliminated the effects of the prior dual system. If the court found that the system had not achieved unitary status, the court would have to give the system specific instruction on how to comply further with the desegregation order. $^{44}$

After the court has found that a system is unitary, Chandler recommends that the court retain jurisdiction over the system for a fixed length of time that each individual court would determine. During this time, the district would have to submit periodic reports to the court detailing the continued racial balance maintained within the system. ${ }^{45}$ At the end of the specified period, the court would then hold another hearing where it would give the original plaintiffs one final opportunity to show why the district should remain under supervision. Then, if there was no showing that the

40. $I d$. at 198.

41. Id. at $202-03$.

42. Id. at 198.

43. Thomas E. Chandler, The End of School Busing? School Desegregation and the Finding of Unitary Status, 40 OKLA. L. REV. 519, 553 (1987).

44. Id.

45. Id. at 554 . 
school should remain under the desegregation order, the court would relinquish all control over the school district. ${ }^{46}$

In actuality, Chandler's plan is not very different from the status quo. His main contribution is adding the second stage of hearings, which would require school systems to remain under court orders even after being declared unitary. One benefit that this second hearing might provide is that parents would have some notice as to when their child's school assignment would change, since the court has to specify the length of time between the initial unitary status finding and the second hearing that would remove the district from court supervision.

Chandler's plan, however, suffers from a number of weaknesses. First, his plan requires the school board to initiate the proceedings to be released from the court order. The problem with this requirement is that school districts often are motivated to remain under court orders indefinitely. Evidence demonstrates that several school districts have fought to remain under court supervision even though these districts recognized that there was nothing more they could do to comply with the court order. For instance, one school system has attempted to remain under court supervision so that it could continue to use race-based student assignments to its magnet schools, which would be unconstitutional if the court lifted the desegregation order. ${ }^{47}$ In this instance, if the court had allowed the school system to remain under the court order, it would essentially have given the system a mandate to engage in the unconstitutional practice of using racebased preferences for magnet school admissions even though the system had already done everything practicable to eliminate the vestiges of the prior dual system. ${ }^{48}$

In addition, there are other motivations for school districts to want to remain under supervision even after they have complied with their court orders. For example, schools may want to remain under court orders indefinitely so that they can continue to receive certain state and federal funds that they can no longer obtain when they have achieved unitary status. ${ }^{49}$ Furthermore, many school boards want to preserve the court orders

46. Id. at 555 .

47. See infra Sections IV.B, IV.D (discussing the Charlotte-Mecklenburg School System's fight to remain under court supervision after it had complied fully with its desegregation order).

48. See infra Sections IV.B, IV.D.

49. When testifying before Congress, Alfred Lindseth, an attorney with extensive experience representing school systems seeking unitary status, stated that a number of school systems do not wish for the courts to release them from supervision, because they do not want to lose their courtordered funding. James E. Ryan, Schools, Race, and Money, 109 Y ALE L.J. 249, 262 n.41 (1999) (citing Assessing the Impact of Judicial Taxation on Local Communities: Hearing Before the Subcomm. on Administrative Oversight and the Courts of the Senate Comm. on the Judiciary, 104th Cong., 1996 WL 538968 (1996) (statement of Alfred A. Lindseth)). Several examples of school systems that Lindseth cited were St. Louis and Kansas City, and he suggested that school districts in other states such as Illinois and Georgia had also joined plaintiffs in resisting a finding 
because they believe there is a benefit to maintaining a racially balanced staff at each school. ${ }^{50}$ However, they fear that if the court order is removed they will be under increasing pressure, often from leaders in the AfricanAmerican community, to replace their current staffing policies with a "role model" policy. ${ }^{51}$ This new type of policy would assign teachers and principals disproportionately to match the predominant race at each school. As a result, school systems might not ever initiate the proceedings for courts to remove them from supervision, even though being released from the court order might be in the best interest of their students.

Another problem with Chandler's plan is that the court would only give the school system feedback on its progress toward achieving unitary status ex post. Therefore, school systems might operate under court supervision for years without recognizing that they are violating the court order. Last, one other troublesome component is that the plan recommends that the school system remain under court supervision for a period of time even after the court has made a finding that the district has achieved unitary status. This provision of the plan strongly conflicts with the mandate that schools should return to local control as quickly as possible.

\section{B. The Twelve-Year Plan}

None of the plans offered by other scholars attempt to specify the length of time that school systems must operate under desegregation orders prior to achieving unitary status. As a result, these plans do not address the problems that result when school systems remain under court orders for too long. At least one scholar has recognized the problems inherent in this ambiguous procedure. Chris Hansen has noted:

Courts, which by their nature are used to finite projects with a definite beginning and a certain, usually prompt end, are increasingly uncomfortable with school desegregation, which appears to have no end. Courts, which by their nature are used to success when decisions are issued and then executed, are increasingly frustrated by their inability to achieve success... in these cases. Simply put, they are giving up. ${ }^{52}$

Consequently, the key to defining unitary status more clearly is to develop a concrete procedure for school systems and courts to follow that

that they had achieved unitary status in order to continue to receive funding. Id.; see also DAVID J. ARMOR, FORCED JUSTICE: SCHOOL DESEGREGATION AND THE LAW 215 (1995).

50. Id.

51. Id.

52. Chris Hansen, Are the Courts Giving Up? Current Issues in School Desegregation, 42 EMORY L.J. 863, 864 (1993). 
specifies the length of time the system has to comply with its court order and that requires more accountability during the supervision period. In most school desegregation cases, the district court developed the court order, and it took the schools a few years to change their policies in order to satisfy the court. Then the court removed the case from its docket until some outside party chose to reintroduce the matter, which could take several decades.

In light of the problems that plague the current system, this Note argues that court supervision should end in all cases twelve years after the court has removed the case from its docket, as long as the district has maintained its level of compliance during that time. The twelve-year time period would begin on the date that the school system has fully begun to implement its court-approved desegregation plan. During these twelve years, all of the students who were in grades K-12 in the segregated school system would have the opportunity to graduate, and the court desegregation order would truly be remedial. This approach accords with the Supreme Court's decisions in Swann and Keyes, ${ }^{53}$ as it focuses on the victims of the de jure segregation in question.

The selection of a mandated twelve-year period of supervision is supported by a study conducted by Robert Crain and Rita Mahard. This study revealed that "desegregation beginning in first grade or kindergarten and continuing through later years produced much better results in terms of achievement gains than desegregation beginning at higher grade levels." 54 Consequently, it seems that a desegregation order could not remedy the effects of the prior dual system to the extent practicable unless it remained in place until the students in kindergarten the year before the plan's implementation had graduated from high school.

The twelve-year plan would also require the courts to maintain a closer watch on the district's compliance with the desegregation order while the schools are under supervision. ${ }^{55}$ Admittedly, the courts do not have the time or money to micromanage every decision that a school district makes with regard to its desegregation plans. However, the school system could submit annual reports to the court detailing its desegregation progress and giving an account of how it is addressing all of the Green factors. Furthermore, the system would have to explain any activities that deviate from the desegregation plan and its rationale for any major decisions, such as where it is building new schools. It does not help anyone for a court to notify a school district that a school-siting decision is segregative ten years after the district has made the decision. These reports would address this problem.

53. See supra note 31.

54. Orfield \& Thronson, supra note 28 , at 778 .

55. Wendy Parker has also argued that judges should be more actively involved in monitoring the progress of school systems in desegregating their schools. Wendy Parker, The Future of School Desegregation, 94 Nw. U. L. REV. 1157, 1161, 1210-20 (2000). 
At the end of this twelve-year period, the court would release the school district from its supervision and give control back to the local boards.

To assist the courts with the monitoring required by this proposal, the twelve-year plan would insist that from the beginning, the court and school system work together to develop a detailed outline of the court's expectations regarding each of the Green factors. For all of these factors, the court would set forth quantifiable measurements to assess the school system's compliance and would explain the rationale behind these measurements. Certainly, no two school systems are the same, so it would be difficult to develop uniform quantifiable measurements for each Green factor that would apply to every school system. It is possible, however, for each court to determine first its individual goals for each Green factor. Then it can determine quantifiable ways to measure these goals based on an analysis of what is feasible for each individual school system. For instance, to assess compliance with the Green factor of student assignment, a court might accept Willie and Fultz's recommendation that a school system ensure that none of its schools has a student body comprised of less than a certain percentage of racial minorities. However, Willie and Fultz's suggestion of twenty percent might not be appropriate for every school system because no school system has the same demographic makeup as another. Therefore, the court could develop a standard for each school system based upon its demographics and the underlying goal that all students receive the benefit of an integrated education.

One positive result of having the court develop standards to measure a district's compliance with each Green factor ex ante is that when the court later has to analyze a school system's annual report, the court has a set of indicators to use when evaluating the system's progress. Another benefit of this requirement is that it ensures that, from the beginning, the school system has a reasonable expectation of what the court requires from it concerning its compliance with the desegregation order. The current regime is fundamentally unfair in this respect because school systems often do not have a clear conception of the courts' expectations until they have operated under the court order for a number of years, and a suit has been brought to request a finding of unitary status.

Admittedly, one problem with developing quantitative standards concerning the Green factors ex ante is that the court might not have a clear idea of what is truly possible for a school system to achieve. Consequently, at least during the first few years of supervision, some degree of flexibility would have to be built into the system to allow for some small deviations that the district may make from these concrete standards. When analyzing any deviations reported in a system's annual report, the court would hold the system to the same good faith standard that courts currently use when analyzing a district's actions to comply with a desegregation order. In 
addition, the court would have the ability to modify the expectations at any time during the twelve-year period, as it gained more information about what the school system is capable of achieving with regard to becoming unitary.

One question that arises concerning the twelve-year plan is what courts should do if they find that the school system has adopted new segregative policies during this time. Certainly the courts would require the system to change such practices immediately. The more important question, however, is whether the twelve-year period should start again upon this determination. In deciding whether to restart the twelve-year count, the court should examine evidence concerning the school system's intent when it adopted these segregative practices. If it appears the school system was making a good faith effort to comply with the desegregation order, and these policies resulted because they were either the only practicable choice available $^{56}$ or because of an honest mistake, ${ }^{57}$ the court should not restart the count. However, if there is evidence that the system was not making a good faith effort to comply with the court order when it adopted these policies, then the court should restart the twelve-year count.

\section{Benefits of the Twelve-Year Plan}

The twelve-year plan provides many benefits that the status quo does not offer. Most importantly, the twelve-year plan counteracts the four main problems that result when courts maintain supervision over school districts under desegregation orders for prolonged periods of time. First, these school systems often become complacent and lack both the ability and the incentive to change their policies to focus on their students' greatest needs. The twelve-year plan, however, would limit the duration of the desegregation order, so that at the end of the twelve-year period, school districts would have the opportunity to determine what is the best way to ensure that all students continue to receive a quality education.

Second, when schools currently want the courts to release them from supervision, they typically have to spend thousands of dollars in litigation fees to achieve this goal. Under the twelve-year plan, however, the court would release the district at the end of this specified time period. Furthermore, the court would have monitored the district's progress during this time and notified the district if it had committed an infraction.

56. An example of such an unavoidable choice would be the school system's decision to construct a new school in a wealthy, predominantly white neighborhood because this land was the only suitable property available, even though the majority of the system's schools were already located in white neighborhoods.

57. For instance, it is possible that a system might make a mistake in developing either its student- or faculty-assignment plan that creates a significant racial imbalance at one of its schools. 
Admittedly, this more extensive monitoring would cause the school system and the courts to incur additional costs. It is much easier, however, for the system to argue that a specific act has not violated the desegregation order than to argue that it has achieved unitary status in all capacities.

In addition, another problem with the current system is that it does not provide parents with a reasonable expectation of when the court will remove the desegregation order, which may cause their children's assignment plans to change. Under the twelve-year plan, parents would have a clear idea of when the student assignments based on the desegregation order would end. One problem with both the current system and the twelve-year plan is the unfairness of making students transfer from one school to another while they are in the middle of their tenure at that school. For instance, a tenth-grade student should not have to transfer to a new school to finish high school. Consequently, under the twelve-year plan, it is highly advisable to allow students to complete the highest grade available at the school they are currently attending when the desegregation order ends.

Also, when schools remain under desegregation orders for prolonged periods of time, they begin to address racial imbalances caused by de facto segregation as well as de jure segregation. The twelve-year plan would curb this problem ${ }^{58}$ by limiting the duration of desegregation orders. Finally, from a political standpoint, one final benefit of the twelve-year plan is that it takes much of the pressure off of local school boards, which are typically elected. The twelve-year plan predetermines the time frame of the desegregation order, so school boards do not have to worry about the political ramifications of requesting that the court remove the district from supervision. Furthermore, with the court providing more extensive oversight throughout the entire process, school boards would have less incentive to consider political repercussions when making decisions that affect the Green factors.

\section{Potential Criticisms of the Twelve-Year Plan and Responses}

While the benefits of the twelve-year plan are clear, there are five main criticisms of the plan that could be raised. The most obvious is the question of whether twelve years is long enough for a school district to remedy the harms caused by the prior de jure segregation. For example, Gary Orfield and David Thronson argue that in many past unitary status hearings, courts have removed desegregation orders before school districts have effectuated

58. On why addressing de facto segregation under federal court orders is a problem, see infra text following note 61 . 
true change. ${ }^{59}$ They further assert that negative ramifications occur when courts declare school systems unitary before the systems have remedied their past violations. ${ }^{60}$ Their main concern, however, stems from the belief that as soon as a school system is released from court supervision it will become resegregated due to residential segregation. ${ }^{61}$

Orfield and Thronson lose sight of the fact that desegregation orders were not intended to address de facto segregation. Consequently, while it is problematic that some schools become resegregated after courts remove desegregation orders, federal desegregation orders are not the appropriate solution to this problem. Instead, new solutions must be developed to address this issue. If we admit that no practical solutions exist to remedy residential segregation, then this concession would mean that school districts would have to remain under desegregation orders forever.

Moreover, a court should seriously scrutinize any proposed desegregation plan that could not achieve desegregation in twelve years, and force the school district to make adjustments to it. This scrutiny alone would be more helpful than the status quo because currently many school districts simply remain stagnant under their desegregation orders. They do not make any changes to effectuate further desegregation, and they force their students to suffer the negative consequences of remaining under desegregation orders for too long.

Furthermore, the policy arguments that critics such as Orfield and Thronson raise to justify prolonged court supervision as necessary to prevent resegregation do not account for the harms that result when schools remain under court orders for too long. In fact, a close analysis of these policy arguments demonstrates that none of them justifies the continuation of court supervision over public schools for a prolonged period of time.

First, some critics who oppose the discontinuation of court supervision assert that once schools are released from their desegregation orders, the achievement gap between white students and black students will increase. Consequently, the only way to ensure that the gap continues to close is to continue to operate schools under the desegregation plans that ensure a balanced makeup of the student body. ${ }^{62}$ However, extensive studies by leading social science and school desegregation expert David Armor

59. See Orfield \& Thronson, supra note 28 , at $759-60$.

60. See id. at 761. This Note agrees with Orfield and Thronson's argument that resegregation within the public schools creates many problems. It argues, however, that there are a number of ways to address these concerns even after courts release schools from supervision. See infra Part V.

61. Id. at 771 (criticizing a federal court for not considering "changing birth rates, the pattern of white suburbanization that existed long before the busing plan, or the large declines in white enrollment that took place in other similar central cities with neighborhood schools" when dismantling a court desegregation order).

62. See David Amor, The End of School Desegregation and the Achievement Gap, 28 HASTINGS CONST. L.Q. 629, 637 (2001). 
demonstrate that, at present, there is no evidence that schools that are still under desegregation orders are diminishing the achievement gap between black and white students. ${ }^{63}$ While the achievement gap did decrease slightly when desegregation was implemented on a wide scale in the 1970s, the gap has begun to increase since the late 1980s, even though desegregation has not been dismantled to a significant degree.$^{64}$ Armor notes that since 1986, white students' math scores on the National Assessment of Educational Progress (NAEP) tests have continued to rise while the scores of black students have remained constant. ${ }^{65}$ Similarly, after 1988, an analysis of these test scores shows that the reading scores of white students have risen, while the test scores of black students have declined. Most persuasive is Armor's conclusion that, at present, black students in schools under court orders achieve at the same rates as black students attending de facto segregated schools. ${ }^{66}$

Secondly, these critics assert that ending the court orders will be detrimental to students, because resegregation will ensure that students will be forced to learn in single-race environments. ${ }^{67}$ On the other hand, when students attend desegregated schools they have the opportunity to work together and learn from one another as well as gain an appreciation for the cultural pluralism of American society. ${ }^{68}$ In the same vein, these critics argue that schools that are integrated "require[] parents of all races to work together to improve the educational quality of a common school. By compelling blacks and whites to cooperate in facing joint problems on a local level, school integration presents invaluable opportunities for the exercise of interracial cooperation and the discovery of convergent interests." $" 69$

However, these arguments lack adequate support for a number of reasons. For instance, in many schools still under court orders, racially segregated classes have still been created through practices such as tracking, which divides students into classes by their perceived ability. ${ }^{70}$ These practices make it difficult for students to have meaningful

63. Id. at 642 (stating that "unlike the time of Brown, there is no reasonable way that school segregation can be invoked as a primary cause of this achievement gap, nor is there any credible evidence that school desegregation -in the form of racial balancing-has diminished the gap to any important degree").

64. Id. at 632,635 .

65. Id. at 632 .

66. Id. at 653 .

67. See Mark V. Tushnet, The "We've Done Enough" Theory of School Desegregation, 39 How. L.J. 767, 771 (1996).

68. Book Note, The Desegregation Dilemma, 109 HARV. L. REV. 1144, 1148 (1996) (reviewing ARMOR, supra note 49).

69. Id.

70. Jack W. Londen, School Desegregation and Tracking: A Dual System Within Schools, 29 U.S.F. L. REV. 705, 710 (1995) (arguing that " $[\mathrm{t}]$ racking is of particular concern in school districts that are under desegregation remedial orders"). 
interactions with individuals of other races while at school. ${ }^{71}$ Furthermore, research has shown that as desegregation continues, fewer and fewer white students remain in the public schools due both to demographic reasons and white flight. ${ }^{72}$ This fact further decreases the possibility that students in desegregated schools will be exposed to students of a different race.

In addition, while in theory desegregated schools teach an appreciation for cultural diversity, studies have shown the opposite to be true. Armor has noted:

One of the central sociological hypotheses in the integration policy model is that integration should reduce racial stereotypes, increase tolerance, and generally improve race relations. Needless to say, we were quite surprised when our data failed to verify this axiom. Our surprise was increased substantially when we discovered that, in fact, the converse appears to be true. The data suggests that, under the circumstances obtaining in these studies, integration heightens racial identity and consciousness, enhances ideologies that promote racial segregation, and reduces opportunities for actual contact between the races. ${ }^{33}$

Also, while it is laudable to hope that parents of different races will have the opportunity to interact as they work for the benefit of their children's school, in actuality, desegregation has actually led to an overall decline in parental involvement at schools under court orders. ${ }^{74}$

The other main argument that scholars raise to oppose the perceived premature release of schools from court orders is the concern that after the desegregation orders end, schools with a majority of black students will not receive adequate funding and without this financial support, these schools will not produce desirable educational outcomes. ${ }^{75}$ For instance, Orfield and Thronson argue that nonjudicial mechanisms cannot ensure that districts achieve equity among their resegregated schools. ${ }^{76}$ However, even if this unfortunate result occurred, ending the desegregation orders would not foreclose the opportunity for concerned parents to litigate this matter.

There are several other arguments that individuals might raise in opposition to the twelve-year plan. For instance, critics might argue that

71. See Days, supra note 26 , at 55 (recognizing that racially segregated classes limit the likelihood that students of different races will have contact with one another).

72. ARMOR, supra note 49 , at 8.

73. Lino A. GRaglia, Disaster by DeCree: The Supreme Court DeCiSions on Race AND THE SCHOOLS 276 (1976) (quoting David Armor, The Evidence on Busing, PUB. INT., Summer 1972, at 90,102 ).

74. Id. at 265; see also Days, supra note 26 , at $57-58$ (noting that a number of blacks believe that ending desegregation orders will increase the involvement of parents and the community in public schools).

75. Tushnet, supra note 67 , at 772 .

76. Orfield \& Thronson, supra note 28 , at 761 . 
this proposal contradicts the basic theory upon which it is premised, because it would require a school system to remain under court supervision for twelve years, even if the system had complied with its desegregation order in a shorter period of time. After all, courts have found that some systems have complied with their orders in as short as five $\mathrm{e}^{77}$ or seven ${ }^{78}$ years. The twelve-year plan, however, does not simply select an arbitrary number of years during which a school system has to maintain acceptable racial ratios among students and faculty at each of its schools. Instead, this proposal is predicated on the assumption that the school system has substantially harmed all students that it has forced to attend segregated schools.

Consequently, to remedy this harm, the system should be required to implement the policies mandated by the desegregation order until all students who had standing ${ }^{79}$ in the desegregation case have a chance to graduate. This group would include all of the students that were in the school system the year before it implemented the desegregation plan. Also, to enable a desegregation order to "overcome the cumulative impact of generations of unequal opportunity, ${ }^{, 80}$ the order must be in place long enough for one class of students to cycle through the entire public education system.

Another potential criticism is that the twelve-year plan will not really reduce litigation costs and has the potential to increase them. This concern would arise from the fact that during every year of court supervision, the court has to scrutinize an annual report and make a finding on whether the district has complied in good faith with the desegregation order. Community members who oppose the release of the district from court supervision may use each of these opportunities to oppose a finding of good faith in an effort to convince the court to restart the twelve-year supervision period. This potential problem is one of the main reasons that the twelveyear plan requires courts to develop clear and quantitative standards ex ante to measure the district's progress. If the numbers clearly show that the school system is complying with the quantitative indicators developed by the court, this fact might discourage frivolous litigation. Furthermore, litigation is expensive, which might dissuade these groups from contesting the court's findings each year. In addition, one of the main reasons that litigating unitary status is currently so expensive is that schools have to

77. See Bd. of Educ. v. Dowell, 498 U.S. 237, 241 (1991) (discussing a 1977 court order finding compliance with and dissolving the 1972 school desegregation program).

78. United States v. Mun. Separate Sch. Dist., 414 F. Supp. 1336, 1337 (N.D. Miss. 1976).

79. See generally Los Angeles v. Lyons, 461 U.S. 95 (1983) (stating that an individual has standing to litigate a constitutional claim if (1) the individual has suffered an injury, (2) the defendant caused the injury, and (3) the judicial relief the individual has requested can redress the injury).

80. Orfield \& Thronson, supra note 28 , at 760 
accumulate information from long periods of time-sometimes thirty years - to show that they have complied with the order. Under the twelveyear plan, however, the schools would only have to prove their compliance with regard to one year.

An additional criticism that might be raised concerning the twelve-year plan is that it potentially gives the judiciary the impossible task of developing an adequate desegregation plan ex ante. After all, what if the school system complies with the court order in good faith for twelve years, but the desegregation plan was simply unsatisfactory from the beginning? Under the twelve-year plan, the court can only restart the twelve-year time period if the school system has not been complying with the court order in good faith. Consequently, these critics would question why the students within the school system should be punished for the judiciary's shortcomings. The clearest response to this criticism is that the twelve-year plan does not expect the judiciary to develop a perfect desegregation plan from the beginning. The plan allows the court to make modifications to the desegregation plan throughout the process. Furthermore, it seems highly unlikely that a court would develop a completely dysfunctional plan even at the beginning of the twelve-year period. It is much more likely that the court will develop a plan that requires minor tweaking throughout the process. Since it is clear that a number of harms result when a school system remains under a desegregation order for too long, it would be a mistake to require a school system to remain under court supervision while the court engages in an unlimited period of trial and error to develop the perfect plan before starting the twelve-year period of compliance. Instead, it seems that a twelve-year proposal that allows modification of the desegregation plan throughout the process is the best solution.

Finally, critics might argue that since there is strong evidence that school systems often want to remain under court orders, the twelve-year plan should encompass some measures to prevent school systems from intentionally failing to comply with the court order during the latter years of the order so as to restart the twelve-year count. Hopefully, in most cases, the court would be able to detect this type of behavior, and recognize it as bad faith noncompliance if the school system had been able to meet the goals of the desegregation order in past years. One misguided way for courts to address this concern would be through a deterrence mechanism, such as imposing monetary sanctions on school systems if they do not comply in good faith with the court order at any stage in the process. For example, these school systems could be deemed ineligible for the funds that the federal and state governments make available to schools under court orders. This solution is not preferable, however, because the individuals most harmed by monetary sanctions are the children in the school system. Therefore, to address this concern, it is important to point out that most 
school systems that would want to remain under court orders are systems that are deeply committed to the ideal of integrated education that desegregation orders promote. Thus, it seems unlikely that these systems would commit egregious actions to violate the order simply to remain subject to it in the future. Furthermore, it seems that it would be apparent to the court that the school system is engaging in this type of behavior. As a result, it appears that the best way for the court to proceed in this situation is to criticize the system's actions openly, but also to allow the twelve-year count to continue. While this solution may not seem the ideal way to deal with this problem, as a policy matter, courts should not make a practice of allowing systems to succeed in manipulating the process in this manner, thereby encouraging more systems to engage in unconscionable conduct.

\section{A CASE Study of THE CharlotTe-MecklenbuRG SCHOOL SYSTEM}

The preceding analysis of the potential criticisms that confront the twelve-year plan actually provides strong support for the merits of this proposal. However, to demonstrate better the problems inherent in the current system and the benefits that the adoption of the twelve-year plan would create, it is helpful to analyze the experience of a school system that remained under its court order for an unnecessarily long period of time. The Charlotte-Mecklenburg School System (CMS) is the perfect example. CMS received national attention in 1971 when the Supreme Court approved a plan to use busing to desegregate its schools in the landmark case Swann $v$. Charlotte-Mecklenburg Board of Education. ${ }^{81}$ Busing is the most dramatic step that the courts have approved for school districts to use to desegregate schools, and CMS was the first system to implement this solution. However, thirty years after the Court approved the busing plan, CMS remained under the court order. While the court could have released the system from supervision many years earlier, the court required CMS to remain under supervision, thereby harming the system's students and parents.

\section{A. The 1971 Swann Decision}

The Swann litigation began on January 19, 1965, when Julius Chambers, an attorney representing several African-American families in Charlotte, North Carolina, filed a lawsuit against the CharlotteMecklenburg School Board attacking the Board's failure to fulfill its desegregation obligations. At the time Chambers filed the lawsuit, $98 \%$ of

81. 402 U.S. 1 (1971). 
Charlotte's African-American students $(19,510$ out of 20,000) attended allAfrican-American schools. Of the 490 pupils who did not attend allAfrican-American schools, more than $80 \%$ were enrolled at a school that only had seven white students. ${ }^{82}$

District Court Judge James McMillan ruled in favor of the plaintiffs, requiring the school district to develop a plan that would completely desegregate the system's schools by the fall of $1970 .{ }^{83}$ When the school district failed to produce an acceptable remedy, McMillan asked an outside expert on school administration, Dr. John A. Finger, Jr., to develop a plan for the court to review. ${ }^{84}$

The plan Finger developed would change the face of school desegregation. Finger called for the desegregation of all 105 of the Charlotte-Mecklenburg schools by using free transportation to create more acceptable racial ratios among the schools. ${ }^{85}$ In a landmark 9-0 decision, the Burger Court required the school district to implement immediately the Finger Plan in its entirety, thereby accepting the use of busing as a tool to desegregate schools. ${ }^{86}$ The school board then diligently implemented the requirements of the desegregation order, and the district court removed the case from its active docket on July $11,1975 .^{87}$

CMS's success in desegregating its schools gained national recognition. In 1984, the National Education Association commended Charlotte for being an example of a city where desegregation was working, ${ }^{88}$ and scholars and educators lauded the area as "The City That Made Busing Work." $" 89$

\section{B. Capacchione Threatens To End the Swann Desegregation Order}

In response to the ever-changing demographic patterns of the city, the school system continued to alter its student-assignment plan to ensure that all schools had balanced racial ratios. In 1992, CMS modified its schoolassignment plan to include the use of magnet schools. ${ }^{90}$ The system

82. BERNARD SCHWARTZ, SWANN'S WAY: THE SCHOOL BUSING CASE AND THE SUPREME COURT 8 (1986).

83. Id. at 16 .

84. Swann, 402 U.S. at 8 .

85. SCHWARTZ, supra note 82, at 18-19; see also Swann, 402 U.S. at 9-10 (noting that Finger deviated from the school board's plan and proposed the use of busing for elementary schools as well as for junior and senior high schools).

86. Swann, 402 U.S. at 32.

87. Capacchione v. Charlotte-Mecklenburg Sch., 57 F. Supp. 2d 228, 236 (W.D.N.C. 1999), aff d sub nom. Belk v. Charlotte-Mecklenburg Bd. of Educ., 269 F.3d 305, 335 (4th Cir. 2001) (en banc), cert. denied, 122 S. Ct. 1537 (2002).

88. SCHWARTZ, supra note 82, at 192.

89. William W.E. Robinson, From DESEgREgation to RESEgRegation IN THE CHARLOTTE-MECKLENBURG PUBLIC SCHOOLS: IS BUSING WORTH THE RIDE? 4 (1991).

90. Capacchione, 57 F. Supp. 2d at 239. 
developed this new policy initiative largely to address the racial imbalance occurring because of the shifts in demographic patterns, which were outside the school system's control.

However, CMS's development of the magnet schools program prompted the reopening of the Swann litigation. On September 5, 1997, William Capacchione filed a complaint against CMS on behalf of his daughter Cristina, who was denied admission to a magnet school by CMS because of the school's enforcement of a rigid racial quota system resulting from the school district's desegregation order. ${ }^{91}$ Cristina Capacchione was classified as "non-black" because she is Hispanic and Caucasian. The school no longer had any spaces available for "non-black students" and, consequently, refused to give her admission. ${ }^{92}$

CMS responded to the Capacchiones' complaint by arguing that its magnet school admissions program did not violate the Fourteenth Amendment. The school system claimed that the program was a remedial measure that it took to comply with the desegregation requirements issued under the Swann order. Furthermore, CMS maintained that the admissions program should remain in place because the system had not yet eliminated all of the vestiges of Charlotte-Mecklenburg's previous dual school system.

At the same time the school system issued its response to the Capacchiones' complaint, the original Swann plaintiffs filed to reopen their lawsuit. They concurred with the school system's assertion that it had not yet satisfied its requirements under the Swann decision, and they requested that the district court retain the desegregation order. The district court consolidated these two cases. ${ }^{93}$

In determining whether or not CMS had achieved unitary status, the court examined the progress of the school system with respect to the Green factors, and found that CMS had complied with the court order "to the extent practicable." 94 Some of the strongest evidence District Court Judge Potter cited was the fact that the Swann plaintiffs had not had to file any motions for further relief since the Court issued the final order in Swann. Also, the court had not had to "enjoin or sanction CMS for noncompliance." $" 95$ Furthermore, by continually adjusting student attendance zones when schools became racially unbalanced due to demographic shifts and private choices, the court was of the opinion that CMS had "gone above and beyond what the [Swann] orders required."

\footnotetext{
91. Id.

92. Id.

93. Id. at $239-40$.

94. Id at 284 .

95. Id. at 282 .

96. Id.
} 
The court's ruling that CMS had achieved unitary status dictated its decision concerning the school district's magnet school admissions policy. The court used strict scrutiny to analyze whether the use of racial criteria in student admissions was appropriate, considering whether the program served a compelling state interest and whether the system had narrowly tailored it. ${ }^{97}$ Judge Potter was particularly critical of the fact that the CMS magnet schools rigidly ensured that they achieved the $40 / 60$ racial balance by mandating that "slots reserved for one race will not be filled by students of another race." J88 Judge Potter most likely viewed this practice as analogous to the controversial admissions policy employed by the University of California at Davis in Regents of the University of California v. Bakke. ${ }^{99}$ In Bakke, the Supreme Court invalidated the Davis admissions policy because it reserved spots for minorities for which nonminorities could not compete. The plaintiffs in Capacchione presented specific evidence of instances where seats at magnet schools remained vacant at the beginning of the school year because not enough applicants of the desired race applied to fill them, even after the school had heavily recruited members of that race. ${ }^{100}$ The court ruled that the magnet school admissions program was unconstitutional because the system had not narrowly tailored it to address the inequities created by the previous dual system.

\section{Conflicting Fourth Circuit Decisions in Belk v. Charlotte-Mecklenburg Board of Education}

The Swann litigation seemed closed after the district court ruled that the system had achieved unitary status. However, on November 30, 2000, the Fourth Circuit Court of Appeals issued a two-to-one decision in Belk v. Charlotte-Mecklenburg Board of Education that reversed a large part of the district court's prior ruling in Capacchione. ${ }^{101}$ The majority, consisting of Judges Motz and King, found that CMS had not achieved unitary status with regard to student assignment, facilities, transportation, and student achievement. ${ }^{102}$

Furthermore, the court ruled that the system's current magnet school admissions policy did not violate the Fourteenth Amendment because it was

97. In Adarand Constructors, Inc. v. Pena, the Supreme Court defined the strict scrutiny test, stating that all racial classifications have to serve a compelling state interest and have to be narrowly tailored to further this intercst. 515 U.S. 200, 220 (1995).

98. Capacchione, 57 F. Supp. 2d at 287 (quoting CMS's 1992 Student Assignment Plan).

99. 438 U.S. 265 (1978).

100. 57 F. Supp. $2 d$ at 288.

101. 233 F.3d 232 (4th Cir. 2000), rev'd en banc, 269 F.3d 305, 317 (4th Cir. 2001), cert. denied, 122 S. Ct. 1537 (2002).

102. Id. at 266. 
designed to facilitate the system's desegregation plan. ${ }^{103}$ When considering the issue of student assignment, the appellate court focused on factors such as CMS's failure to obey court orders concerning where to construct new schools. ${ }^{104}$ The court's main concern was that CMS had constructed the majority of its new facilities since the Swann ruling in suburban white communities. ${ }^{105}$

While the court conceded that there was no evidence that the school system was intentionally trying to recreate a dual system, the court felt that this action was still suspect under the Swann order, and it remanded this issue to the district court for reconsideration. ${ }^{106}$ The appellate court also emphasized its concern that African-American students had more heavily borne the burden of busing than white students, and that this fact violated the original court decree. ${ }^{107}$ It used this evidence as proof that the school system had not done everything it could to eliminate the vestiges of prior segregation. ${ }^{108}$

In addition, the court gave much credence to the fact that the school board had taken "the remarkable step of admitting its noncompliance with prior orders in this case."109 The Capacchione plaintiffs appealed the decision, and the Fourth Circuit agreed to hear the case en banc. ${ }^{110}$ The court reviewed the district court's ruling for clear error and found none. ${ }^{111}$ Consequently, the court ordered the removal of the desegregation order and returned the schools to the local control of the school board. ${ }^{112}$ In addition, the court affirmed the trial court's ruling that the system could no longer use race-based quotas when making magnet school assignments. ${ }^{113}$

\section{An Analysis of the Conflicting Decisions}

After conducting an analysis of all of the facts from Capacchione and Belk, it is surprising that the three-judge panel found that the school system had not complied with the court desegregation order concerning student assignment, facilities, transportation, and student achievement. The evidence overwhelmingly indicated that the system had done everything

103. Id. at 276

104. Id at 255

105. Id. at 256 .

106. Id. at 256-57.

107. Id. at 257 . The court found it particularly alarming that currently eighty percent of the children who ride buses are African Americans. Id. at 263-64.

108. Id. at 257.

109. Id. at 257-58.

110. Belk v. Charlotte-Mecklenburg Bd. of Educ., 269 F.3d 305, 317 (4th Cir. 2001) (en banc), cert. denied, 122 S. Ct. 1537 (2002)

111. Id. at 335

112. Id. at 312 .

113. Id. at $342-43$. 
that it could to achieve its desegregation goal. The district court found that during the last thirty years "an overwhelming majority ... generally, $70 \%$ to $100 \%$ " of the schools in the school system have been racially balanced, and no all-black or all-white schools had existed during this time. ${ }^{114}$ Furthermore, at least one study had indicated that CMS had facilitated a higher amount of racial integration than a number of school systems across the country had achieved when courts declared that they had attained unitary status. ${ }^{115}$ In fact, while testifying before the court during the Capacchione litigation, the superintendent of CMS, Eric Smith, admitted that he could not specify any further benefit that the school system would gain from remaining under court supervision. ${ }^{116}$

The system's record in terms of school-siting decisions was laudable. Approximately nine years ago, CMS voluntarily adopted a policy that it would not construct new schools in areas where black residents did not constitute at least ten percent of the population. ${ }^{117}$ Furthermore, the district court found that for a number of years CMS had worked to combat imbalances resulting from de facto segregation, even though it had no obligation to address this problem. ${ }^{118}$

Moreover, when the court issued the desegregation order in 1969, it originally found that the African-American schools were not inferior to the white schools. ${ }^{119}$ In addition, during the Capacchione litigation, the plaintiffs did not present any evidence demonstrating that the school system implemented any intentionally discriminatory policies concerning facilities since the court issued the desegregation order. ${ }^{120}$ Consequently, the court's consideration of the school system's facilities should have been moot. Finally, with regard to transportation, the original court order only required the system to provide transportation to all students indiscriminately. ${ }^{121}$ The defendants in the Capacchione litigation conceded that the school system had complied with this requirement. ${ }^{122}$

It is puzzling why the Fourth Circuit judges in the 2000 Belk decision ruled that CMS had not complied with the desegregation order and why CMS fought so hard to remain under court control, insisting that it was at fault for not having done everything that it could have to comply with the court desegregation order. After all, from the beginning, CMS was one of

114. Capacchione v. Charlotte-Mecklenburg Sch., 57 F. Supp. 2d 228, 248 (W.D.N.C. 1999), aff d sub nom. Belk, 269 F.3d 305, cert. denied, 122 S. Ct. 1537 (2002).

115. Belk, 269 F.3d at 320. This study was conducted by David Armor, an expert who testified for the plaintiffs in the Capacchione litigation.

116. 57 F. Supp. $2 d$ at 293.

117. Belk, 269 F.3d at 324.

118. Capacchione, 57 F. Supp. $2 \mathrm{~d}$ at 251-52.

119. Belk, 269 F.3d at 329.

120. Capacchione, 57 F. Supp. $2 d$ at 267.

121. Id.

122. Id. 
the school districts in the South that was least resistant to complying with Brown. ${ }^{123}$ It began admitting a small number of black students into its formerly all-white schools in 1957. In fact, even before the Supreme Court issued the Swann decision, "no southern city, and only two non-southern cities, had achieved as much racial mixing in its public schools as had Charlotte." 124 One would expect a school system to bristle at having to remain under court supervision-especially since the evidence is clear that CMS has worked very hard to comply with the Swann order.

However, CMS had a special incentive to want to remain under the court order indefinitely. The Fourth Circuit has made it clear that only school systems that are under desegregation orders can consider race when making assignments to magnet schools. ${ }^{125}$ As a result, since the court has lifted the desegregation order, CMS will no longer be able to consider race when granting admission to magnet schools. Furthermore, the system can no longer justify its policies as remedying the vestiges of past discrimination. This realization explains why CMS and some parents wanted the system to remain under the order, as the Fourth Circuit has intimated that remedial action could be the only compelling state interest that legitimates the use of race-based distinctions. ${ }^{126}$ Consequently, in theory, strict scrutiny could be "fatal in fact" 127 to any future race-based assignment policies that CMS may choose to implement since the court has removed the desegregation order.

\section{E. The Benefits the Twelve-Year Plan Would Have Given to CMS}

The experience of CMS clearly demonstrates the four main problems that school systems experience when courts do not remove desegregation orders for a prolonged period of time. For thirty years, CMS did not have the freedom or incentive to adopt creative new assignment plans, which

123. In Brown v. Board of Education, the Supreme Court required that all school districts cease segregating their student populations by race. 347 U.S. 483 (1954).

124. Douglas, supra note 26 , at 1-2.

125. In Tuttle v. Arlington County School Board, the Fourth Circuit found that an altemative kindergarten could not use a weighted lottery system with race-based preferences to determine admissions. 195 F.3d 698, 705 (4th Cir. 1999). Similarly, in Eisenberg v. Montgomery County Public Schools, the Fourth Circuit found that the Montgomery County Board of Education could not deny a student the right to transfer to a magnet school because of his race. 197 F.3d 123 (4th Cir. 1999).

126. City of Richmond v. J.A. Croson Co., 488 U.S. 469 (1989) (holding that a government program requiring contractors to subcontract a certain percentage of their work to minorities was not narrowly tailored to remedy past discrimination and was therefore unconstitutional); Hopwood v. Texas, 78 F.3d 932 (5th Cir. 1996) (concluding that a law school's affirmative action plan was not designed to remedy past wrongs and was thus unconstitutional).

127. Ironically, in Adarand Constructors, Inc. v. Pena, Justice O'Connor stated that the Court "wish[ed] to dispel the notion that strict scrutiny is 'strict in theory, but fatal in fact." 515 U.S. 200,237 (1995) (citation omitted). 
would address its students' needs more adequately. ${ }^{128}$ Furthermore, as a result of the Supreme Court's unclear standard of what constitutes unitary status, CMS recently spent thousands of dollars litigating Capacchione and Belk that it could have used to fund programs to increase the achievement level of all of its students. Also, during the entire time that it took to resolve the legal disputes concerning the desegregation order, the parents and students in the system remained uncertain about when their studentassignment plan might change and which school they would attend. ${ }^{129}$ In addition, during the three decades that CMS was under court supervision, it continually revised its student-assignment plan to address imbalances caused by changing demographic patterns. ${ }^{130}$ Even more problematic, because the court did not closely monitor CMS's progress while it was under the court order, and the court did not recognize that the system had complied with the court order long before William Capacchione initiated his lawsuit, the court was actually enabling the school system to engage in unconstitutional behavior.

In contrast, if the Supreme Court had adopted the twelve-year plan when it began requiring schools to desegregate, the experience of CMS would have been very different. Under the twelve-year plan, court supervision of CMS would have begun with the 1975-1976 school year ${ }^{131}$ and would have ended at the close of the 1986-1987 school year. Since CMS did not start to use magnet schools until 1992, the problem concerning student assignment to these schools would not have arisen. Furthermore, the system would have never denied Cristina Capacchione admission to a magnet school because of her race. In addition, the twelveyear plan would have prevented the system's unnecessary expenditures on

128. See infra Part V.

129. When Judge Potter found that CMS was unitary in September 1999, he mandated that the system implement a new student-assignment plan for the 2000-2001 school year. CharlotteMecklenburg Sch. Sys., The History of Public Schools in Charlotte-Mecklenburg (Sept. 15, 2002), at http://www.cms.k12.nc.us/discover/history.asp. The following November, the school system unveiled a new assignment plan; however, when the Fourth Circuit stayed Judge Potter's ruling in December, this action meant that the school system was not required to implement the new plan. Id. Then, in June 2000, the Board of Education adopted a new assignment plan for the 2001-2002 school year. This plan had to be discarded in December 2000 after the Fourth Circuit found that the system was not unitary in some arcas. Id. After the Fourth Circuit ruled en banc in September 2001 that the system was unitary, the system once again launched a new studentassignment plan that would take effect during the 2002-2003 school year. Id. Yet, since the Belk plaintiffs appealed to the Supreme Court, parents in the school system did not know whether the new plan would indeed take effect until the Court announced in April 2002 that it would not hear the case. Id.

130. Capacchione v. Charlotte-Mecklenburg Sch., 57 F. Supp. 2d 228, 282 (W.D.N.C. 1999), aff'd sub nom. Belk v. Charlotte-Mecklenburg Bd. of Educ., 269 F.3d 305 (4th Cir. 2001) (en banc), cert. denied, 122 S. Ct. 1537 (2002).

131. The exact date that the school system began to implement the court-approved plan is uncertain; however, the date that the court removed the case from its active docket was July 11, 1975. Capacchione, 57 F. Supp. 2 d. at 236. Consequently, I have selected this date as a starting point. 
litigation fees and the stressful confusion parents and students faced concerning their future school placements. It also would have eliminated the majority of the system's activities to adjust assignment plans to combat de facto desegregation, which school systems under desegregation orders are not required to address.

Moreover, during the 2000 Belk litigation, the court questioned a number of the decisions CMS had made while it was under the court order. For instance, the court was suspicious of the fact that the system had built "twenty-five of twenty-seven new schools in predominately white suburban communities." 132 While the evidence does not suggest that the system made these decisions with the intent of placing a greater burden on AfricanAmerican students than white students, under the twelve-year plan, the school system would have had to submit annual reports to the court explaining its decisions concerning school sitings and other Green factors. Consequently, the court would have had the opportunity to view these decisions in the aggregate throughout the time it supervised the system to determine if there was a pattern demonstrating a segregative intent. Finally, and perhaps most importantly, under the twelve-year plan, the system would have regained full control of its schools in twelve years, and after the court removed the order, the system could have focused on concerns that were more important to parents and students than continuing efforts of perfecting integration. ${ }^{133}$

\section{RESPONSES TO OTHER CONCERNS THE TWELVE-YEAR PLAN MAY GENERATE}

An examination of the CMS litigation clearly shows how the twelveyear plan would have prevented the four major problems faced by schools that remain under desegregation orders too long. It also brings to light several more concerns individuals may have about the twelve-year plan. However, a careful analysis of the steps CMS has taken since the court removed its desegregation order reveals that these concerns are unfounded and actually support the acceptance of the twelve-year plan.

\section{A. Schools Can Still Continue To Use Busing}

One potential concern critics might raise in opposition to the twelveyear plan is that after twelve years, schools could no longer use busing to create diversity in their nonmagnet schools even if they still feel that

132. Belk v. Charlotte-Mecklenburg Bd. of Educ., 233 F.3d 232, 256 (4th Cir. 2000), rev'd en banc, 269 F.3d 305, cert. denied, 122 S. Ct. 1537 (2002).

133. See infra Subsection V.B.2. 
diversity is an important goal. In actuality, however, school systems can still use busing to facilitate this goal even after courts remove their desegregation orders.

Admittedly, it is unclear whether schools could make assignments to public nonmagnet schools based on race after the court removes the desegregation order and still use busing to achieve this objective. However, Professor John Charles Boger has argued that the use of racial classifications in making assignments to public elementary and secondary schools is vastly different from the use of racial classifications that the courts have prohibited in cases like Bakke, Croson, and Hopwood. ${ }^{134}$ Unlike employment or higher education, students in nonmagnet public schools are not competing for a finite number of spaces. Every student who wants the benefit of a public education in the school system has this opportunity. However, applicants for admission to a certain university, a specific job, or a government contract have no guarantee that they will receive that for which they have applied because there are a limited number of spaces available. ${ }^{135}$

The Fourteenth Amendment simply promises individuals that " $[\mathrm{n}] \mathrm{o}$ State shall make or enforce any law which shall ... deny to any person within its jurisdiction the equal protection of the laws." ${ }^{136}$ Consequently, it is arguable that "there is no 'federal right' granted to any parent or child that assures them attendance at any particular public school. For legal purposes, public schools are deemed equivalent and fungible."137

While this argument is logical, in order to infringe upon students' rights and bus them to schools that are further from their homes than their neighborhood school, a compelling state interest must exist. ${ }^{138}$ At present, the Supreme Court has not decided whether diversity is a compelling state interest. ${ }^{139}$ However, regardless of what the Supreme Court decides concerning this question, a school system could still use busing to create diversity in its nonmagnet public schools by making student assignments using wealth as a criterion. The Supreme Court has held that wealth is not a suspect classification..$^{40}$

134. John Charles Boger, Willful Colorblindness: The New Racial Piety and the Resegregation of Public Schools, 78 N.C. L. REV. 1719, 1762-64 (2000).

135. Magnet schools fall into the same category as institutions of higher education because they have a limited number of spaces available.

136. U.S. CONST. amend. XIV, $\$ 1$.

137. Boger, supra note 134 , at 1764.

138. Adarand Constructors, Inc. v. Pena, 515 U.S. 200, 220 (1995) (holding that race-based actions taken by the state must reflect a compelling state interest and that the means to achieve this goal must be narrowly tailored).

139. Gratz v. Bollinger, 122 F. Supp. 2d 811,821 (E.D. Mich. 2000) (noting that the Supreme Court has never explicitly decided whether diversity is a compelling state interest), rev'd sub nom. Grutter v. Bollinger, 288 F.3d 732, petition for cert. filed, 71 U.S.L.W. 3154 (U.S. Aug. 9, 2002) (No. 02-241).

140. San Antonio v. Rodriguez, 411 U.S. 1, 20-28 (1973). 
Research demonstrates disturbing correlations between race, wealth, and student achievement. ${ }^{141}$ In North Carolina alone, more than half of the 400,000 African-American students in the state's public schools fail standardized math and reading tests each year, while over eighty percent of white students consistently pass these tests. ${ }^{142}$ Furthermore, studies on a national level show that " $[t]$ hree-fifths of all high poverty schools in the U.S. have majorities of black and Latino students." ${ }^{143}$ Consequently, it seems that this plan serves many of the purposes that race-based schoolassignment policies served under the desegregation order. However, the new plan will probably withstand an attack questioning its constitutionality because the school board is employing race-neutral criteria in its studentassignment policies. It appears that a court would employ rational basis review to analyze the program, as opposed to strict scrutiny, because courts do not consider wealth a suspect classification. Admittedly, the North Carolina Supreme Court recently declared in Leandro v. State ${ }^{144}$ that education is a fundamental right, ${ }^{145}$ and typically the North Carolina courts apply strict scrutiny when a fundamental right is at stake. ${ }^{146}$ There is still a strong chance, however, that the courts would not apply strict scrutiny in this situation.

\section{B. School Systems Will Have More Freedom}

Furthermore, the twelve-year plan is actually a better alternative than the status quo in terms of the future of student-assignment plans because this plan gives districts more freedom to create diversity and equal education opportunities. While under court supervision, school districts have to continue the use of busing to achieve the necessary race-ratios to comply with their desegregation orders. ${ }^{147}$ Busing has always been a controversial solution and is problematic in a number of ways. Once a court releases a school system from supervision, however, the system can continue to use busing to achieve diversity in its nonmagnet schools or it

141. Elizabeth Jean Bower, Answering the Call: Wake County's Commitment to Diversity in Education, 78 N.C. L. REV. 2026, 2040 \& n. 76 (2000).

142. Id. at $2040-41$.

143. Id at 2041 (citing GARY ORFIELD \& JOHN T. YUN, RESEGREGATION IN AMERICAN SCHOOLS (1999), at http://www.law.harvard.edu/civilrights/publications/resegregation99/ resegregation $99 . \mathrm{html})$.

144. 488 S.E.2d 249 (N.C. 1997).

145. Bower, supra note 141 , at 2043.

146. Id. at 2043 \& n.94 (citing Town of Beech Mountain v. County of Watauga, 378 S.E.2d 780,782 (N.C. 1989)).

147. While busing was not the only possible method systems could have used to achieve compulsory integration, the Supreme Court expressed that it was the best way. See Teitelbaum, supra note 25, at 364 (citing Swann v. Charlotte-Mecklenburg Bd. of Educ., 402 U.S. 1, 29-30 (1971)). 
can reevaluate whether it wants to continue busing at all. For instance, after the court removed CMS from supervision, the system opted to implement a neighborhood schools model for its student-assignment plan, which does not include busing for long distances.

\section{The Problems with Busing}

From the beginning of desegregation, the majority of African-American parents have opposed busing. ${ }^{148}$ They have complained that their children had to bear much more of the burden to integrate the schools than white children. In addition, these greater distances were a barrier for parents when they had to speak with their children's teachers or when they wanted to attend PTA meetings. Members of the white community also voiced their opposition to this policy when school systems first implemented it. ${ }^{149}$ In addition, it is staggering to discover that school systems spend "hundreds of thousands or even millions of dollars every year on extra fuel and labor in order to bus students from one neighborhood to another rather than just a few miles to the nearest school."150

Finally, perhaps the best argument against the controversial use of busing is that, hypothetically, the main benefit of busing is that students of different races can interact with one another in the educational environment. The experience of CMS, however, illustrates that this goal was not necessarily achieved. While the system used busing for thirty years to create racial diversity in its schools, the desired interaction of students of different races did not occur because of the school system's use of student tracking. In 1988, researcher Frye Gaillard questioned whether CMS was actually resegregating its students within its schools. ${ }^{151}$ While busing ensured that students of different races attended the same school, Gaillard found that once the students arrived at school, separation by race still occurred in classes, at lunch, and through extracurricular activities. ${ }^{152} \mathrm{CMS}$ divided students into high- and low-ability groups, and the divisions based on ability levels often showed distinct racial imbalances. ${ }^{153}$

In 1991, William Robinson conducted a study to determine whether CMS's use of tracking was actually promoting racial resegregation. ${ }^{154}$ Studying all of the high schools in the system, Robinson found that " $64.5 \%$

148. Mark Nadler, Charlotte-Mecklenburg, in BUSING U.S.A. 310, 312 (Nicholaus Mills ed., 1979); John M. Vickerstaff, Getting off the Bus: Why Many Black Parents Oppose Busing, 27 J.L. \& EDUC. 155,159 (1998).

149. Nadler, supra note 148 , at 310 .

150. Vickerstaff, supra note 148 , at 160.

151. RoBinson, supra note 89 , at 4 .

152. Id.

153. Id. at 5-6.

154. Id. at 8 . 
of all low track courses were ... racially imbalanced with disproportionately more black students, and $58.3 \%$ of all advanced level courses were racially imbalanced in favor of other (nonblack) students." 155 In his study, Robinson cited research that demonstrated the negative effects of tracking on students. Studies have illustrated that low-ability students fall further behind when they are in classes with all low-level students, but that they benefit when they are in classes intermixed with students of all ability levels. ${ }^{156}$ Consequently, Robinson argued that racial tracking in CMS was hurting African-American students, and CMS should limit its use.

\section{The Benefits of a New Neighborhood Schools Plan}

Busing has not proven to be as useful in promoting equal opportunities for students as proponents had hoped, and it has been extremely expensive. However, school systems under desegregation orders have been forced to continue this practice indefinitely. In contrast, under the twelve-year plan, school systems would have the broad freedom to reassess what types of policies most effectively address the needs of their students after twelve years and design their assignment plans accordingly.

The actions of CMS after the court removed its desegregation order illustrate this point. Derrick Bell has observed that even though AfricanAmerican students from the inner city attended wealthier schools because of desegregation, these schools usually funneled the extra money they had into programs for the high-ability groups that white students predominately populated. ${ }^{157}$ Consequently, CMS has developed a new school-assignment plan that it will implement at the start of the 2002-2003 school year. This new plan could potentially address this concern.

Under the new plan, the system has assigned students to a school close to their homes, known as the student's "home school."158 In addition, the system has assigned each student to a "choice zone," which includes elementary, middle, and high schools located close to the students' homes. Each choice zone includes three or four high schools. ${ }^{159}$ Parents have the opportunity to rank school preferences and can choose from any of the schools in the system. ${ }^{160}$ The system has guaranteed students admission to

155. Id. at 35. Robinson defined a racially imbalanced course as "[a] course which deviates from the percentage of black students in the school at large by $+/-20 \%$." Id. at 7.

156. Id. at 45 .

157. Derrick Bell, A Model Alternative Desegregation Plan, in SHADES OF BROWN: NEW PERSPECTIVES ON SCHOOL DESEGREGATION 125, 136 (Derrick Bell cd., 1980).

158. Telephone Interview with Donna Bell, Executive Director for Planning Services, Charlotte Mecklenburg School System (Jan. 31, 2002).

159. Id.

160. Id. 
their home schools. Parents also have the option of selecting a school outside of their child's choice zone. ${ }^{161}$

After the system conducts the initial lottery and makes student assignments, parents have the opportunity to appeal. ${ }^{162}$ The system has promised to give a preference to the appeals of children who receive free or reduced lunch and to whom the system has assigned a school where the proportion of students qualifying for free or reduced lunch is thirty percentage points or more above the system average. ${ }^{163}$

Theoretically, using this new neighborhood schools model, AfricanAmerican students can receive more benefits from their school's resources. To achieve this goal, however, CMS has promised that under the new student-assignment plan, schools that have higher concentrations of lower socioeconomic status students will receive additional resources. ${ }^{164}$ During the Capacchione litigation, the issue of whether the system could allocate supplementary funds to schools arose. Judge Potter ruled that the district could not make these allocations based on race, but he did not preclude the schools from distributing these funds based on the low amount of resources a school currently has available to it. ${ }^{165}$ In the past, other school districts that courts have released from supervision have adopted similar measures. When Prince George's County in Maryland proposed ending busing and moving toward a new policy of neighborhood schools, the school board voted "to spend \$172 million to upgrade neighborhood school buildings and $\$ 174$ million for educational improvements to ensure that all schools had equal facilities and resources." 166

Another important distinction to note between the school system in the pre-Brown era and the system under the new student-assignment plan is that students now have the opportunity to transfer to magnet and nonmagnet schools if they do not like the school to which the system assigns them. Consequently, since parents will have the opportunity to transfer their students, this policy will hopefully encourage CMS to equip all of its schools with adequate resources, so that schools do not become overcrowded with parents transferring their children.

161. Id.

162. Id.

163. Charlotte-Mecklenburg Bd. of Educ., Board Resolution 2001 (Apr. 3, 2001), at http://www.cms.k12.nc.us/studentassignment/boardresolution2001.asp.

164. Telephone Interview with Donna Bell, supra note 158.

165. Celeste Smith, Speakers Challenge Magnet Moves, Changes for Equity, CharLotTE OBSERVER, Nov. 12, 1999, at 1A; Celeste Smith \& Debbie Cenziper, Judge to Schools: No Racial Assignment, CHARLOTTE OBSERVER, Sept. 11, 1999, at 1A.

166. The County Where More Blacks Than Whites Go to College, J. BlaCKS HIGHER EduC., Summer 1995, at 36, 37. 


\section{The System Can Still Achieve Diversity in Its Magnet Schools}

A more challenging concern critics may assert regarding the adoption of the twelve-year plan is that under its implementation, schools would only have the opportunity to create diversity in magnet schools for a short period of time. However, just as schools can still create diversity in nonmagnet schools after desegregation orders are removed, school systems can also create diversity within magnet schools by using wealth as one admission criterion. ${ }^{167}$ An analysis of recent events within CMS regarding magnet school admissions after the court removed the desegregation order demonstrates the feasibility of this option. Certainly in the opinion of CMS, the biggest loss that it will face now that the court has released it from supervision is that it can no longer use racial criteria to create diversity when making magnet schools admissions decisions. However, CMS has addressed this concern in its new student-assignment plan by incorporating wealth-based preferences into its magnet school admissions process. ${ }^{168}$

\section{The Necessary Return to Local Control}

One final argument against the twelve-year plan deals with its limited duration. More specifically, critics may worry that after the court removes the desegregation order, many systems may revert to their former discriminatory practices. However, this concern would exist whether a system remained under court supervision for twelve years or thirty years. Furthermore, one must attempt to balance this concern with the idea that school systems are intended to be under local control.

In Milliken v. Bradley, the Supreme Court made clear that "[n]o single tradition in public education is more deeply rooted than local control over the operation of schools." ${ }^{169}$ It is clear that the Supreme Court foresaw the judicial supervision of desegregation as a temporary measure that would eventually end, and intended for the control of schools to return to local school boards. Consequently, while it is always a possibility that a school district could implement segregative or discriminatory policies in the future, in the long run, it is the responsibility of community activists and voters to prevent this action from happening. These individuals must accept their responsibility to ensure that school systems continue to serve the needs of all of the students within their boundaries regardless of their race.

Moreover, it is important to note that even when a court terminates a desegregation order, concerned parents can bring new litigation if they feel

167. See supra Section V.A (discussing the correlations between wealth, race, and student achievement).

168. Telephone Interview with Donna Bell, supra note 158.

169. 418 U.S. 717,741 (1974). 
that the school system is neglecting the needs of their children. ${ }^{170}$ Furthermore, another benefit to removing the focus from the classic desegregation remedies is that it is possible that this policy has achieved its marginal utility, and parents of African-American children can shift their focus to address new problems. For example, parents could bring a lawsuit that attacks the current curriculum and faculty assignments in their schools if they feel that these components of their children's academic environment are perpetuating a racial hierarchy by failing to embrace diverse racial and cultural perspectives. ${ }^{171}$

In Knight v. Alabama, concerned parents of African-American children brought a lawsuit which "challenged the equality of opportunity afforded African American students in educational institutions that fail to embrace diverse racial and cultural perspectives." 172 Some commentators suggest that concerned parents should seek remedies for "harmful, limiting schooling practices, such as tracking, early special education designation, and disciplinary practices that communicate outside status." 173 Parents could also examine whether racial hierarchies are created by the types of courses that teachers of different races teach. For instance, these parents may feel that the fact that white teachers teach most of the advanced courses in their schools, while minority teachers teach most of the remedial courses, perpetuates racial hierarchy and racial inferiority. In contrast, while school systems have been under desegregation orders, it seems that citizens have operated under the mistaken belief that school systems are not engaging in discriminatory practices. In actuality, however, school systems like CMS have still created inequities through mechanisms like tracking. One benefit of the twelve-year plan is that when school systems are released from supervision after this specified period of time, parents may feel a greater responsibility to monitor their schools' polices than they feel while their schools are operating under court supervision.

\section{CONCLUSION}

Under the twelve-year plan, the court would have released CMS from court supervision in $1987 .{ }^{174}$ Instead, the system remained under court

170. See, e.g., United States v. Corinth Mun. Separate Sch. Dist., 414 F. Supp. 1336, 1346 (N.D. Miss. 1976) (stating that "[i]t seems hardly necessary, in closing this school desegregation case, to remind anyone that the doors of this federal district court remain open to redress grievances condemned by the Constitution and laws of the United States").

171. Ware, supra note 34 , at 482.

172. Id. (citing Knight v. Alabama, 14 F.3d 1534 (1 1 th Cir. 1994)).

173. Id. at 481 n. 64 .

174. The court removed the Swann litigation from its active docket in 1975. Belk v. Charlotte-Mecklenburg Bd. of Educ., 269 F.3d 305, 332 (4th Cir. 2001) (en banc), cert. denied, 122 S. Ct. 1537 (2002). 
supervision for thirty years and fell victim to the four problems that plague school systems that have to remain under desegregation orders for too long. This result is unfortunate because the priorities of parents in 2002 are not the same as the priorities that parents had in 1971. For instance, at present, "more and more Americans-black and white-discount the importance of an integrated education." 175 Today, concerned parents of African-American students are advocating different priorities, such as curbing the unfair practice of tracking, which disproportionately affects black students, and encouraging school systems to redirect the large sums of money spent to bus students away from their neighborhoods to the funding of resources that they feel the schools need much more ${ }^{176}$ However, since CMS was under the desegregation order for thirty years, it lacked the ability to address many of these redefined priorities because its new policies would most likely have violated its court order.

While this dilemma is now over for CMS, it still confronts parents and students in hundreds of school districts. The bell should be tolling for desegregation orders across the country. Instead, more than 400 school districts were still under court supervision in the year 2001. An analysis of the CMS case demonstrates both the benefits this school system will receive now that it is no longer under the court order and the negative ramifications that would have occurred if the system had remained under supervision. It is clear that a more concrete definition of unitary status would have been helpful. What is unclear is why the Supreme Court has hesitated to provide a better definition. The reason that the Court did not elaborate upon the concept of unitary status is not that this concept is not guaranteed by the Constitution. After all, the Fourteenth Amendment articulates the constitutional right of equal protection that unitary school systems promote and dual systems violate.

In addition, the reason that the Court did not more clearly define this term does not seem to be that it felt that it would overstep its bounds by providing further clarification. The Court has already demonstrated great activism when taking control of the school systems, and, in actuality, the courts determine whether or not a school system has complied with the desegregation order. Why not provide concrete standards in the beginning instead of after the system has struggled for years to achieve desegregation?

Another potential explanation for why the Court did not provide clear guidance is that it did not foresee all the negative ramifications that would

175. Douglas, supra note 26, at 2; see also Days, supra note 26, at 54 (explaining that "black parents now express support for school board efforts to end desegregation plans that involve busing, favoring instead a return to neighborhood schools, even though this would result in increases in the number of virtually all-black schools in the inner city").

176. Jeffrey Rosen, The Lost Promise of School Integration, N.Y. TIMES, Apr. 2, 2000, at A23 (stating that eighty-two percent of African-American parents believe that it is more important to raise academic standards than to achieve diversity and integration in the nation's schools). 
occur if school systems languished under desegregation orders. For instance, magnet schools did not exist in 1954 when the Court issued the Brown decision, so the Court could not have envisioned that systems under desegregation orders would leave coveted seats at magnet schools unfilled simply to achieve desired racial ratios. However, while this theory explains why the Court did not expound upon the concept of unitary status in the early years of desegregation, this theory does not explain why the Court has not further clarified this term as school desegregation litigation has evolved.

In fact, the best theory for why the Court has left the concept of unitary status so vague is that it was wary of creating a one-size-fits-all remedy to de jure segregation. However, it seems that there are ways to clarify further the term unitary status without falling into this trap. For instance, while one may believe that the twelve-year plan does create this type of one-size-fitsall solution, one must also remember that a school district would still be working with a district court to create a specialized plan to effectuate desegregation in its district.

Based on this analysis, it seems that the Supreme Court erred when it failed to define the concept of unitary status more clearly. Strong reasons exist to explain why further guidance would have helped. No acceptable justification appears to exist, however, for why the Court did not further clarify this term. When the Court ordered schools to desegregate in 1954, its rationale was that it wanted to ensure that state actors did not use racial classifications to prevent students from receiving equal educational opportunities. Ironically, at present, when the courts require school systems to remain under desegregation orders long after the systems have complied with these orders, state action is preventing students from receiving equal educational opportunities. One of the starkest examples of this point is when school districts will not offer open seats in magnet schools to nonAfrican-American students because their desegregation order requires them to satisfy strict racial ratios when making student assignments.

Similarly, school systems currently hide behind desegregation orders and resegregate students within their schools while failing to address their students' most pressing needs in other ways. Instead of fighting to ensure that schools remain under desegregation orders, parents should focus their litigation efforts on these more pressing problems, which may not violate desegregation orders but are preventing their students from receiving adequate educational opportunities.

In reality, it does not appear that the Court is going to offer further clarification of the term unitary status in the future. It seems that many school districts will remain under desegregation orders indefinitely until we finally understand that ending desegregation orders will not erase all of the progress of the past three decades. Consequently, as the fiftieth anniversary of the Brown decision quickly approaches, the courts should take a more 
active supervisory role over these desegregation decrees and evaluate why 400 schools are still under court supervision. In addition, the courts should make a commitment to helping districts determine what more they must achieve in terms of remedying de jure segregation before the court removes these desegregation orders, so that school systems can have more freedom and incentive to address the ever-changing needs of their students.

Furthermore, recognition of the problems inherent in the Supreme Court's current jurisprudence concerning desegregation orders and of the merits of a proposal like the twelve-year plan has implications for many more school districts than the 400 still under supervision. Currently, one of the most salient issues in education reform is a growing concern about wealth-based segregation. It has long been recognized that this practice does not violate a federal constitutional right. ${ }^{177} \mathrm{~A}$ number of state courts, however, have recently held that their state constitutions recognize education as a fundamental right, ${ }^{178}$ and one state has found that de facto segregation in public schools is unconstitutional. ${ }^{179}$ While the twelve-year plan is tailored to remedy de jure instead of de facto segregation, many of the problems that necessitate a solution like the twelve-year plan in the de jure context also arise in the de facto segregation context. Consequently, state courts will hopefully learn from the mistakes of federal desegregation orders and develop remedies that will effectuate self-sustaining change.

177. ARMOR, supra note 49 , at 56.

178. John A. Powell, Living and Learning: Linking Housing and Education, in IN PURSUTT OF A DREAM DEFERRED 21 (John A. Powell et al. eds., 2001).

179. Sheff v. O'Neill, 678 A.2d 1267, 1289 (Conn. 1996). Instead of developing a specific remedy in Sheff, the court decided that "further judicial intervention should be stayed 'to afford the General Assembly an opportunity to take appropriate legislative action.'" Id. at 1290 (citation omitted). 
***

Imaged with the Permission of Yale Law Journal 